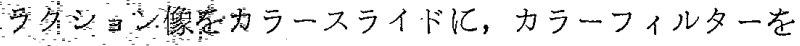

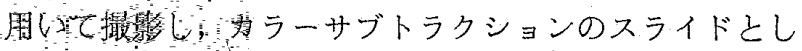

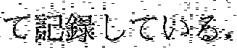

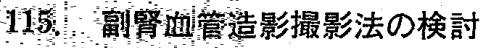

䂣留島大学医学部附属病院 放射線部

阔田 淳德

[rits

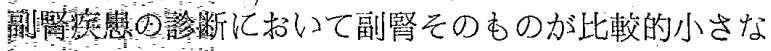

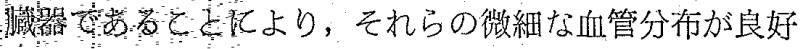

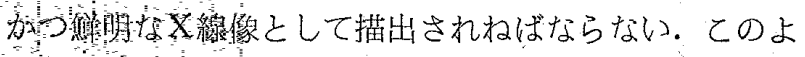

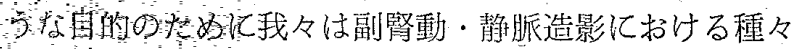

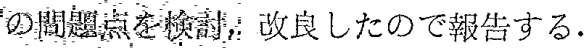

結果

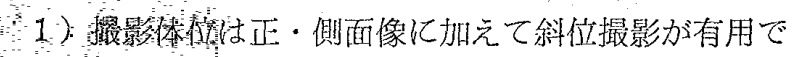

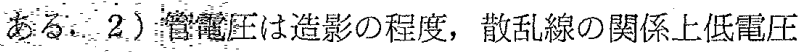

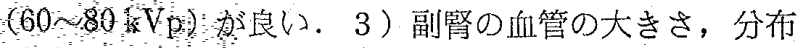

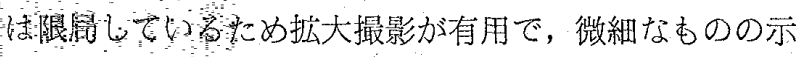

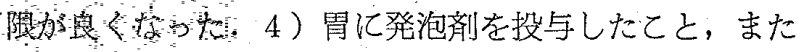

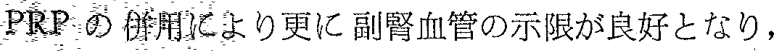

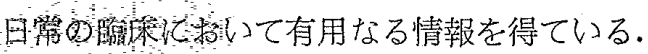

\section{6 千薯がんセンターにおける眼窝静脈撮影法の検} 㒛

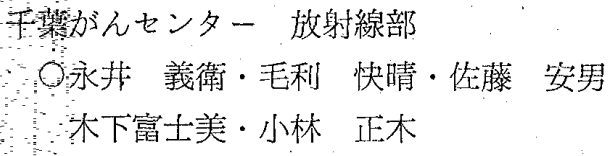

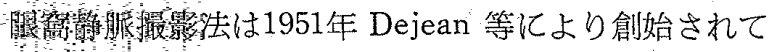

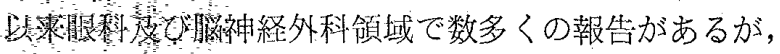

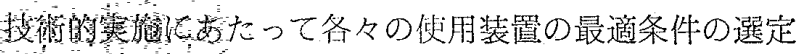

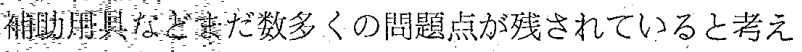

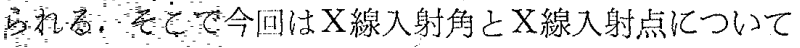

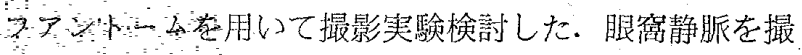

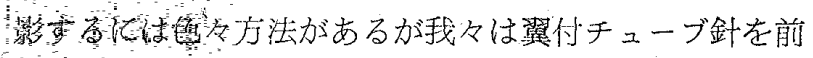

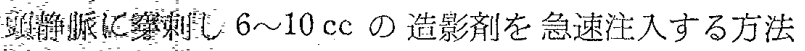

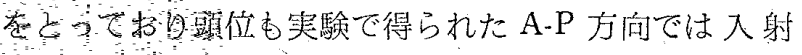

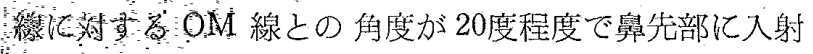
女Lateral Basal の 3 方向立体連続撮影を実施し臨床上

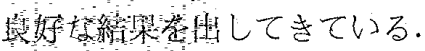

117 Urografin による直接胆のう胆道造影時の最高 Urogrofin 濃度の研究およびその濃度に付随する 諸現象諳条件

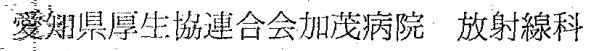

9人来 茂福・大家 忠行・野々山聖治 柴目傑・阔田啓子·真野・重則

毛目的

人体シ・・ーション法で胆石陰影の再現性とウログ
ラ濃度との相互関係について実験。識別限界胆石による 識別限界グラフを描き且つ各胆石陰影の MTF を測定. 総合的に最適ウログラ濃度を決定. 濃度に附随する諸現 象，諸条件について検討を加え，2〜3の知見を得たの で報告する。

〔結果〕

(1) 濃度は $20 \%$ ，撮影電在は $70 \sim 85 \mathrm{kVp}$ が最適であ った. (2) 人体にとって障害となり得ると考えられる最 小胆石 $2 \times 2 \mathrm{~mm} \phi$ の写真上の 再現性の閭題は結果(1)で ほぼ解決出来た。（3）胆石陰影消失变形現象は，60\%造 影時に起り易く，20\%の際には起り得なかった。

\section{I.I. 間接撮影 Angio の実際とその問題点}

関西医科大学附属病院 放射線科

○山 哲男・小林 昭㫜 中川 忠腀・関 善明 東芝メディカル株式会社 恒仙 卓二・西尾 功作 東京芝浦電気株式会社 南博

我々は, 1972年より高解像 I. I. tube (中心部解像力: 40 本 $/ \mathrm{cm}$ ) 乙 $70 \mathrm{~mm}$ Rapid Camera（最高每秒 6 枚撮 影）を組合せた I.I. 閯接連続撮影法で，循環器系の造影 撮影を試みている.I. I. tube を使用しているので，思者

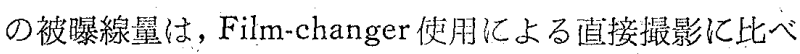
約 $1 / 10$ 亿減少可能である.しかし解像力の点で今一歩直 按撮影汇少る点がある. (Film-changer 使用直接撮影: 40 本 $/ \mathrm{cm}$, I. I. 間接撮影: 25 本 $/ \mathrm{cm}$ ). 比較的太(血管等 を造影する心・大血管造影には十分使用可能と考える. 最近I.I.が高度に改良されたが，I.I. そのものの改善は 屯とより, 間接用カメラ, フィルム，X線管球等，I.I.

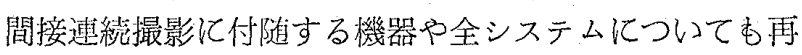
倹討と開発を進好る必要があると考える。

119. スキャノグラフィーによる下肢動脈撮影について 川崎医科大学附属病院

○日地 啓夫 -久保田寿一・沼口 健治 横林 常夫·友光 達志

[目的]

スキャノグラフィーによる研究は古く，血管撮影の導 入も幾多の報告がなされているが今回我々はてれを更に 榆討し少量の造影剤により下肢動脈の全景像を撮影する ことが出来たので報告する。

[方法]

FFD は $100 \mathrm{~cm}$, scanspeed $25 \mathrm{~cm} / \mathrm{sec}$, slit 愊 $1.5 \mathrm{~mm}$, 造影剤アレギオコレインを用い逆行性にて行なった。 〔結果】 